\title{
Factors controlling the biogeochemical cycles of trace elements in fresh and coastal marine waters as revealed by artificial radioisotopes
}

\section{P. H. Santschi ${ }^{1}$}

Swiss Institute for Water Resources and Water Pollution Control, EAWAG, CH-8600 Dübendorf, Switzerland

\begin{abstract}
Radionuclides in aquatic ecosystems can provide important insights into the way physical, chemical, biological, and sedimentological processes are coupled into networks to control the transfer of major and trace elements within the waterbody itself and across its boundaries. Examples from artificial radionuclide studies in freshwater (Experimental Lakes Area in Northern Ontario, ELA) and coastal marine ccosystem enclosures (MERL tanks at Narragansett Bay, Rhode Island) show the cycling of selected trace elements across the sediment-water interface as these are influenced by various biogeochemical factors.

The approach to meaningful studies using radiotracers should include the separate characterization of the physical transport processes, and preferably a comparison of the fate of radiotracers to those of stable elements in the same system, to allow for kinetic studies of chemical forms. The kinetics of transformation of different chemical species of $\mathrm{Co}, \mathrm{Hg}, \mathrm{Ag}, \mathrm{Se}$, and $\mathrm{Cr}$ ions, under variable $\mathrm{pH}$ (ELA) or redox (MERL) conditions appeared to be indirectly linked to the kinetics of organic carbon cycling. A better knowledge of the predominant chemical species of trace elements present in these systems will be important in understanding bioavailability, biomagnification, and toxicity of trace elements in aquatic ecosystems.
\end{abstract}

In recent years, many advances have been made in our ability to measure accurately the concentrations and distributions of most trace elements in the coastal and open ocean. Bruland (1983), in his review on this subject, says that our new analytical capabilities have produced a "quantum leap" in our understanding of trace element chemistry in the ocean. Recent analytical advances have also improved our understanding of lake chemistry. However, the determination of unambiguous and consistent concentration profiles is only the first step in our quest for a full understanding of the biogeochemical cycling of trace elements in natural waters. What is still, at times, lacking is a knowledge of the processes which regulate actual trace element distributions in space and time, and how the various processes are linked to each other. This information can be gained through more innovative applications of radiotracers in aquatic systems. Even though lakes and oceans have drastically different

\footnotetext{
' Current address: Department of Marine Sciences, Texas A\&M University, Galveston 77553-1675.

The careful reviews of this manuscript by R. F. Anderson, B. Honeyman, J. Schnoor, S. Schiff, and two anonymous reviewers, and the support of the Swiss Academy of Sciences (SNG) are acknowledged.
}

physical dimensions and inputs of energy, the controlling processes for elemental cycling are often similar and therefore, both systems can be compared. The basic difference lies in the time scale of the processes and in the energy input to these systems. Due to their smaller size and their much larger ratio of the surface area of the drainage basin to that of the water reservoir, the influcnce of the terrestrial ecosystem is much greater for lakes than for ocean basins. This results in larger relative inputs of terrestrial organic and mineral particles to lakes per unit area, causing lakes to age in geologically short periods of time. Therefore, lakes often exhibit steeper concentration gradients of trace elements in water and sediments. Furthermore, the behavior of trace elements in the water column of lakes is more complicated than in the ocean because trace element profiles are strongly influenced by the following factors: river inputs; atmospheric inputs; removal by plankton and allochthonous material; nonlocal mixing events; and secliment resuspension.

In both systems, the various physical, chemical, biological, and sedimentary processes are interrelated and form a network of processes. The way in which these various processes are coupled is, however, not 
fully understood. To understand the blueprint of processes and their controlling functions, we need a more holistic method of study. Such a method is provided by the use of isotopic tracers. Most important reactions in a water body occur at or near "geochemical boundaries" where the various physical, chemical or biological forces act together and thus control the cycling of elements. Geochemical interfaces include both micro- or macroscopic density gradients, such as the particle-water and the sediment-water interface, the vertical pycnocline caused by temperature or salinity gradients, the horizontal salinity gradient of estuaries, the resuspension layers near the sediment-water interface of coastal areas or the deep sea, and the air-water interface.

Of all geochemical boundaries, the sediment-water interface can exert the greatest control on the cycling of many elements in shallow aquatic environments such as lakes, rivers, estuaries, and coastal embayments. Gradients in physical properties (density), chemical ( $\mathrm{pH}, \mathrm{pE}$, ligand concentrations), and biota abundance (fauna and flora near the sediment-water interface) are greatest across this interface.

The use of natural radionuclides in lake ecosystems or in occan basins can greatly help to place limits on the rates and importance of some of these processes. If we want to gain a more detailed understanding of the factors that control the exchange of trace elements across just one geochemical interface, it is desirable to study these factors in mesocosms enclosing that particular boundary. These enclosures then make possible the use of artificial radiotracers to elucidate the coupling of the various processes at this interface.

\section{Biogeochemical factors}

The cycling of most trace elements is controlled by certain key processes. The controlling process may vary from element to element or between chemical forms (i.e. species) of the same element. However, all of these processes are linked in the environment and ultimately controlled by the input of energy in the form of sunlight and by the supply of nutrients. In the approximate order of increasing characteristic time scale $\left(T_{c}\right)$ for equilibration of the trace element with the particulate phases, these processes include the following.

1. Plankton synthesis in surface waters of lakes and oceans may regulate the concentration of "nutrient-type" elements (e.g. $\mathrm{Cu}, \mathrm{Zn}, \mathrm{Ni}, \mathrm{Se}$, and As, with $T_{c} \approx 10^{-1}$ to $10^{1}$ d) (Bruland 1983; Fisher et al. 1984; Fisher 1986). Other elements with no apparent metabolic function are also controlled by plankton synthesis, perhaps inadvertently. For example, Cd concentrations correlate strongly with those of phosphate, although $\mathrm{Cd}$ is not required for cell growth. Other examples include Be (Measures and Edmond 1983) or the rare earth elements (de Baar et al. 1985).

2. Bacterial degradation of organic carbon in subsurface waters and surface sediments regulates the redox potential of the local environment and, thereby, may control the concentrations of "redox-sensitive" and nutrient-type elements (c.g. $\mathrm{Mn}, \mathrm{Co}, \mathrm{Cr}$, $\mathrm{U}$, and $\mathrm{V}$, with $T_{c} \approx 10^{1}$ to $10^{5} \mathrm{~d}$ ). However, the redox conditions in a particular environment do not affect all radioactive and stable trace elements the same way. In general, elements involved with the $\mathrm{Fe}, \mathrm{C}$, and $\mathrm{Mn}$ redox cycles (e.g. Co and $\mathrm{Mn}$ ) are mobilized in reducing (anoxic) environments while others are mobilized in oxidizing (oxic) environments (e.g. $\mathrm{Cr}, \mathrm{Se}, \mathrm{U}, \mathrm{Pu}$, and V) (Emerson 1985; Collier and Edmond 1984; Graybeal and Heath 1984; Westerlund et al. 1986).

3. Particles settling through a lake, estuary, or ocean water column will control the behavior of certain elements by removing them from the dissolved phase through the formation of nuclide/particle surface site complexes ( $T_{c} \approx 10^{-2}$ to $\left.10^{1} \mathrm{~d}\right)$. Such "scavenging-type" elements include $\mathrm{Fe}, \mathrm{Mn}, \mathrm{Co}$, $\mathrm{Cr}, \mathrm{Pb}, \mathrm{Pu}, \mathrm{Sn}, \mathrm{Pa}$, and $\mathrm{Th}$ (Brewer et al. 1980; Santschi et al. 1980a). For a particular radionuclide, the extent of scavenging by sinking particles depends on the chemical composition of the particle surface. For example, $\mathrm{Fe}_{2} \mathrm{O}_{3}$ and $\mathrm{MnO}_{2}$, precipitated as coatings on suspended particles, will generally have a greater influence on nuclide scavenging than will organic particles, when compared according to an equal number of particle surface complexation sites. How- 
ever, natural particles are often coated by organic carbon (Hunter and Liss 1982).

4. DOC (dissolved organic carbon) peptization and POC (particulate organic carbon) coagulation reactions can thus regulate $\left(T_{c} \approx 10^{-2}\right.$ to $10^{2} \mathrm{~d}$ ) the concentration of organically complexed elements (e.g. $\mathrm{Cu}, \mathrm{Pb}$, and $\mathrm{Hg}$ ). Such reactions are particularly important in coastal waters with high organic loadings and in estuarine systems with large ionic strength gradients (Kerndorf and Schnitzer 1980; Turner et al. 1981).

5. Clay reconstitution reactions can regulate the concentration of elements in sediments which have special affinities for clay minerals $\left(T_{c} \approx 10^{1}\right.$ to generally $>10^{5} \mathrm{~d}$, e.g. $\mathrm{Si}, \mathrm{Al}$, and B) (Mackin 1986, 1987; Mackenzie and Garrels 1966).

It is obvious from these examples that the distribution of a particular element in the water can be regulated by more than one factor leading to its removal, depending on the circumstances. If one input term clearly dominates, element distributions in the water can also be marked by the input functions. Examples include Mn(II) coming from atmospheric and continental sources or ${ }^{210} \mathrm{~Pb}$ coming from atmospheric sources and in situ generation by ${ }^{226} \mathrm{Ra}$ decay. The processes themselves represent a range in geochemical time scales. In this paper I emphasize the details of several of these processes to demonstrate the use of radionuclides and the influence of biochemical factors on trace element regulation in shallow aquatic ecosystems where these factors are strongly linked to each other.

Depending on the particular conditions, several or all of the above mentioned processes can regulate the concentration and spcciation of a certain trace element. More often than not, the absolute concentration of a trace element in an ecosystem does not determine its toxicity or bioaccumulation, but rather it is another factor, such as the content of reactive amorphous iron oxide, manganese oxide, or organic carbon in the food particles or dissolved in the water, which controls the solubility or bioavailability of the trace element.

For example, Li et al. (1984) found a drastically different sorption behavior of radioactive $\mathrm{Hg}, \mathrm{Ir}, \mathrm{Au}$, and $\mathrm{Sb}$ on different natural solids (sediments, montmorillonite, etc.), depending on the kind of seawater usedsurface or deep ocean water. UV irradiation of surface seawater in these uptake experiments lowered the partitioning of these radionuclides to the same particles, resulting in particle associations similar to those in deep ocean water. The enhanced sorption in surface ocean water was ascribed to the effect of DOC on the sorption behavior of these nuclides.

Furthermore, the redox state of many elements in the aquatic environment is not only regulated directly by the biological activities of plankton and bacteria and their exudates but also indirectly by photochemical and surface catalyzed reactions. Table 1 gives some examples of the recent literature on this subject, drawn from both laboratory and field studies.

The time scales of several microbially or surface-catalyzed redox reactions in natural aquatic systems are compared for selected minor and trace elements in Fig. 1. Since most of those reactions are coupled (in series or in parallel), it is important to know the time constants for these coupled reactions. If in series, the slowest one controls the overall reaction rate; if in parallel, it is the fastest onc. The fastest reactions on top are simple electron, proton, and ligand exchange reactions, while the slowest reactions often involve the breakage of covalent chemical bonds. Inorganically controlled sorption-desorption reactions of trace elements on particle surfaces are often coupled to selective incorporation by plankton or to microbially or photochemically mediated conversion reactions at those particle surfaces (Table 1). Biogeochemical factors can determine the rates at which equilibrium distributions of redox-sensitive trace element species are established. It has been found for many elements that equilibrium distributions of chemical species are not always observed.

Thermodynamic equilibrium calculations often reflect only the static conditions in an ecosystem. Analytical identification of the different species in an aquatic ecosystem and the determination of the rates of transformations of these kinetic intermediates are important in understanding the controls and 
Table 1. Comparison of biogeochemical factors that determine the rates at which equilibrium distributions of redox-sensitive trace element species are established. (Arrows represent predominant redox transition.)

\begin{tabular}{|c|c|c|}
\hline Biogeochemical factors & Example of affected trace element & References \\
\hline Particle surfaces & $\begin{array}{l}\mathrm{Cr}(\mathrm{III}, \leftrightarrow \mathrm{VI}) \\
\mathrm{Pu}(\mathrm{IV}, \leftarrow \mathrm{V})\end{array}$ & $\begin{array}{l}\text { Amdurer } 1983 \\
\text { Nelson et al. 1984; Sanchez et al. } \\
1985\end{array}$ \\
\hline Bacteria & $\mathrm{Hg}(\mathrm{II}, \leftrightarrow 0)$ & $\begin{array}{l}\text { Wood 1985; Pan-Hou and Imoura } \\
1982\end{array}$ \\
\hline $\begin{array}{l}\text { Complexation by fulvic and } \\
\text { humic acids }\end{array}$ & $\begin{array}{l}\mathrm{Fc}(\mathrm{II}, \leftrightarrow \text { III }) \\
\mathrm{Hg}(\mathrm{II}, 0), \mathrm{V}(\mathrm{III}, \mathrm{V}), \mathrm{Fe}(\mathrm{II}, \mathrm{III}) \\
\mathrm{Pu}(\mathrm{IV}, \leftarrow \mathrm{V})\end{array}$ & $\begin{array}{l}\text { Theis and Singer } 1974 \\
\text { Kerndorf and Schnitzer 1980; Buffle } \\
1984 \text {, and references therein } \\
\text { Nelson et al. } 1984\end{array}$ \\
\hline $\mathrm{MnO}_{2}$ & $\mathrm{Co}(\mathrm{II}, \rightarrow \mathrm{III})$ & Murray and Dillard 1979 \\
\hline $\begin{array}{l}\text { Primary production and respi- } \\
\text { ration }\end{array}$ & $\mathrm{Se}(-\mathrm{II}, \leftrightarrow 0, \leftrightarrow \mathrm{IV}, \leftrightarrow \mathrm{VI})$ & Cutter and Bruland 1984 \\
\hline Light & $\begin{array}{l}\mathrm{Pu}(\mathrm{IV}, \leftarrow \mathrm{V}, \rightarrow \mathrm{VI}) \text { on goethite } \\
\mathrm{Fe}(\mathrm{III}, \rightarrow \mathrm{II}) \text { on phytoplankton } \\
\mathrm{Cr}(\mathrm{III}, \leftarrow \mathrm{VI}) \text { with DOC } \\
\mathrm{Cu}(\mathrm{II}, \rightarrow \mathrm{I}) \text { with DOC } \\
\mathrm{Cu}(\mathrm{II}, \rightarrow \mathrm{I}) \text { on goethite and bir- } \\
\text { nessitc }\end{array}$ & $\begin{array}{l}\text { Keeney-Kennicutt and Morse } 1985 \\
\text { Hudson and Morel } 1985 \\
\text { Riedel } 1985 \\
\text { Moffett and Zika } 1985 \\
\text { Morse and Huerta-Diaz } 1985\end{array}$ \\
\hline
\end{tabular}

interactions of an element in that ecosystem. For this purpose, isotope techniques have proven quite useful.

\section{Importance and kinetics of trace element-organic associations in aquatic ecosystems}

At lower concentrations, many trace elements act as micronutrients and are essential for the growth of certain organisms, although at higher levels they can be toxic. Often the gap between the optimal and toxic concentration is quite small. It appears that particle affinity and the tendency to form complexes (in the absence of significant concentrations of DOC) with hydroxyl and carboxyl groups and toxicity to marine plankton are related (Fisher 1986). Deviations from this rclationship might be causcd by the presence of nonlabile DOC complexes, as the toxicity to biota is controlled by the prevalent chemical form (i.e. speciation) of the trace element present in the system. Inorganic and especially organic complexation or other forms of covalent binding can control toxicity to organisms, bioaccumulation (Leppard 1983), and food chain magnification in ecosystems. For example, free aquo-copper $\left(\mathrm{Cu}^{2+}\right)$ is considered to be more toxic than organically complexed forms (Sunda and Guillard 1976), while com- plexed forms of some B-metals (e.g. neutral or charged complexed species of $\mathrm{Hg}, \mathrm{Ag}$ ) might penetrate cell walls to a greater extent than the free ions (Langston and Bryan 1984). Furthermore, competition by other ions, primarily major ions such as $\mathrm{Ca}^{2+}$, $\mathrm{Mg}^{2+}, \mathrm{Na}^{+}$, and $\mathrm{K}^{+}$, and by dissolved organic carbon, can modify the effects and pathways of trace elements in ecosystems. Since the residence time of organic carbon in living systems is short compared to its residence time as nonliving breakdown products, trace element distributions can be as much affected by dissolved or particulate organic carbon as they are by uptake into living biomass.

Dissolved organic carbon molecules can have an accelerating or decelerating effect on the removal or cycling of a trace element. The critical point is whether the organic ligand of the trace element is increasing (as a ternary surface complex) or decreasing (as a binary solution complex) the extent of adsorption to the particle surface (Schindler 1981) or the diffusion through cell membranes (Langston and Bryan 1984).

Complex formation constants of trace metals with humic matter significantly correlate with those for hydroxide or carbonate complexing (Turner et al. 1981) as they bind mainly via phenolate and carboxylate 
Bate

Fe (II) oxidation (water)

Oxygen consumption (sediment)

Fe(III) photoreduction (water)

Acetate production (sediment)

Nitrate consumption (sediment)

Amino acid production (sediment)

Denitrification (sediment)

Organic carbon production (water)

Sulfide production or oxidation (sediment)

Sulfate reduction (sediment)

Manganese (II) oxidation (water)

Selenite reduction (water)

Ammonia production (sediment)

Chromium (III) oxidation (water)

Organic carbon degradation ( $4^{\circ} \mathrm{C}$ water)

Methane oxidation (water)

Pyrite formation (sediment)

Selenate reduction (water)

Manganese (II) oxidation (sediment)

Organic carbon degradation (sediment)

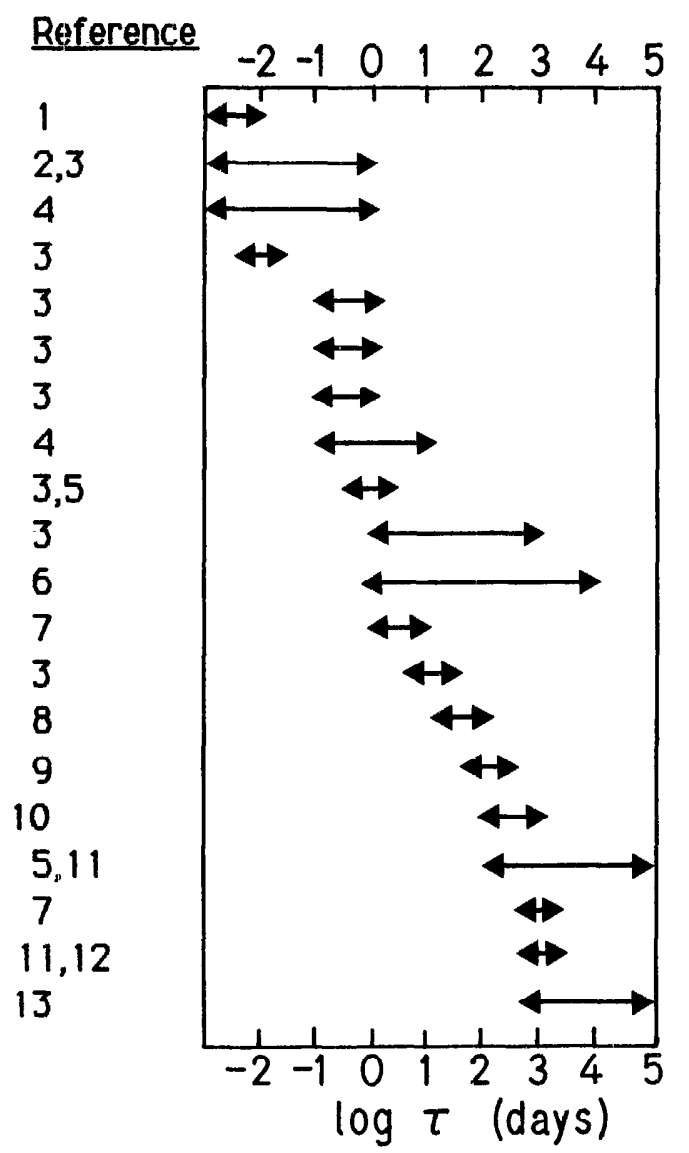

\section{References}

1. Kester et al. 1975; Murray and Gill 1978; Aller 1980

2. $\downarrow 6 r$ gensen and Revsbech 1985

3. Review by Reeburgh 1983

4. Review by Morgan and Stone 1985

5. King et al. 1985

6. Nyffeler et al. 1984; Emerson et al. 1982; Sung and Morgan 1981; Aller 1980

7. Santschi et al. 1987

8. Amdurer 1983

9. Gardner et al. 1983

10. Bopp et al. 1981

11. Berner 1984

12. Robbins and Callender 1975

13. Grundmanis and Murray 1982; Emerson 1985

Fig. 1. Turnover or conversion residence times of chemical species in microbially mediated redox reactions as determined by both isotope and conventional techniques. 
groups. Complex formation of trace metals to natural organic matter of any kind (humic and fulvic acids) is generally more important in freshwater than in seawater environments. There is less competition by the major ions for binding to organic carbon and by other inorganic anions such as chloride for the trace metal ion in freshwater environments, Furthermore, purely inorganic trace metal speciation is more variable in freshwater environments due to compositional and $\mathrm{pH}$ differences in different lake and river systems. For both types of systems, however, the tendency of hydrated cationic species to form complexes with different types of ligands is related to the concept of A- and B-type cations, introduced by Ahrland (Ahrland et al. 1958), and the concept of hard and soft ions, introduced by Pearson (1969).

\section{Radiotracer studies in enclosed ecosystems}

Artificial radionuclides can generally be uscd as rescarch tools only in containcd natural "ecosystems."

Aquatic enclosures of various sizes ranging from beakers to aquaria to whole lake basins have been used for various purposes and described in the literature (Grice et al. 1982; Giesy 1980; Schindler 1973; Schindler et al. 1980). They have been successfully used in studies of ecosystem function and structure, in ecotoxicological studies at chronic exposure levels, and in studies of biogeochemical factors in coastal or lake ecosystems of practical importance is the ability to account for all relevant fluxes.

Artificial radionuclides, when used in such enclosures, have several important advantages: the study of the "unperturbed" system is possible both in a biological (no toxicity or "stress") and in a chemical (trace element stays at natural concentrations) sense; the analytical methods are both simple and ultra-sensitive (i.e. the determination of the element at pM levels of concentration is possible) with few contamination problems; one can "target" specific processes by using specific radionuclides and follow these processes in time.

Thcoretical considerations and laboratory-scale experiments often result in a hy- pothesis of the fate of trace elements in a natural system that can be tested in such enclosed ecosystems. Radiotracers can then be used to test our current understanding of the various interacting biological, chemical, or physical processes in ecosystems.

For a successful radiotracer study in an enclosed ecosystem, the following approach has been most fruitful. 1 . The transport system and its sorptive capacity must be fully characterized (e.g. the particle production, concentration, aggregation, and flux; the physical boundary layer; filtering rates by benthic or pelagic fauna; rates of biologically controlled particle mixing and resuspension across the sediment-water interface). Examples include Santschi et al. (1986) and Nyffeler et al. (1986) (ELA) or Adler et al. (1980), Amdurer et al. (1982, 1983) and Santschi et al. (1982, 1983, 1987) (MERL). 2 . It must be shown that radionuclides serve as tracers for the fate of their stable counterparts in enclosed ecosystems [e.g. Anderson et al. 1987 (ELA); Santschi et al. 1987 (MERL)] and that results from such studies are not invalidated by slow isotopic exchange reactions. 3 . If 1 and 2 have been addressed, the interpretation of in situ chemical studies in enclosures is greatly facilitated. For example, the identification of different chemical forms of one element, and the kinetics of transformation of one form into another, or the diagenetic mobilization of trace elements in sediments can be studied in a more fruitful way. Predictions about the potential for remobilization of trace elements in aquatic ecosystems that are based on simple laboratory-scale speciation and leaching experiments can then be tested in such enclosures (e.g. Amdurer et al. 1982; Santschi et al. 1983, 1986, 1987).

A critical review of the use of radiotracers as predictive tools for trace element cycling is given in the following sections. Emphasis is placed on their use to test our understanding of the transport system and the conversion rates of chemical forms.

Experimental approaches to the study of the transformation of chemical forms

Although it is clear from laboratory experiments that metal-organic associations 
affect the extent of uptake by the biota, the rates of transformations of different chemical species of an element and the effect of dissolved and particulate organic carbon, $\mathrm{MnO}_{2}$, or sunlight on these rates are not well understood. To illustrate this point, I will discuss results from radiotracer experiments in enclosed ecosystems in freshwater lakes (Experimental Lakes Area) and coastal areas (Narragansett Bay).

Using a few elements as examples (i.e. the A-type cation $\mathrm{Cr}^{3+}$, the "borderline" A- cations $\mathrm{Co}^{2+}, \mathrm{Mn}^{2+}$, the B-type cations $\mathrm{Hg}^{2+}$, $\mathrm{Ag}^{+}$, and the redox-sensitive hard anions of Se), I will show what biogeochemical behavior is unique at the ecosystem level, rather than in sterile laboratory environments. I will also show which of the five key processes mentioned above (i.e. plankton uptake, organic carbon mineralization, iron and manganese oxide precipitation, DOC and POC complexation, peptization, and coagulation reactions, clay reconstitution reactions) most likely controls element cycling.

The enclosures used in the Experimental Lakes Area (ELA), Northern Ontario are described elsewhere (Emerson et al. 1973; Schindler et al. 1980; Hesslein et al. 1980; Santschi et al. 1986). Those used by Santschi et al (1986) were $1 \mathrm{~m}$ high, $1 \mathrm{~m}$ in diameter, and anchored to the sediments. Some of them were used without sediments on the bottom to study only water-column processes. The ELA lakes are soft-water lakes moderately high in dissolved organic carbon and low in ionic strength.

The mesocosms of the Marine Ecosystems Research Laboratory (MERL tanks) in Narragansett Bay, Rhode Island, are described in numerous publications (see Santschi 1985 for recent review). They consist of a 5-m-high and 1.8-m-diameter water column, overlying a layer of $30-\mathrm{cm}-\mathrm{decp}$ natural sediments. The water, with an average salinity of $30 \%$, is mixed in such a way as to simulate tidal action, i.e. $2 \mathrm{~h}$ on, $4 \mathrm{~h}$ off. Radiotracers have been added as a pulse to the water column, and the redistribution in various phases (e.g. water, phytoplankton, zooplankton, fecal pellets, sediments, pore waters, surface layer at the water-air interface, or the walls) has been monitored over time (Amdurer 1983; Amdurer et al. 1982, 1983; Adler et al. 1980; Santschi et al. 1982, 1983, 1986, 1987).

The kinetics of conversion of different chemical forms of $\mathrm{Co}, \mathrm{Se}, \mathrm{Cr}, \mathrm{Hg}$, and $\mathrm{Ag}$ isotopes and their sensitivity to chemical perturbations in enclosure ecosystems is discussed below. Even though the techniques used are empirical in nature (i.e. filtration through $0.45-\mu \mathrm{m}$ Nuclepore followed by extractions through charcoal, Chelex, anion exchangers, Amberlite, and Amicon ultrafiltration for water samples, and ion exchanging, reducing, oxidizing, and strong-acid-extractable leaches for sediment samples), they illustrate the effects of different chemical forms on transport behavior. All these elements exist in several oxidation states in natural water and have been known from previous experiments to be involved in reactions with specific organic molecules. It is expected that organic associations of these elements would modify their chemical behavior in a natural ecosystem.

T'o study the nature and "robustness" of the particle associations in the natural system. I carried out experimental perturbations such as acid and base additions at ELA and back-diffusion experiments from sediments under oxic or anoxic conditions (asphyxiation technique, Rutgers van der Loeff et al. 1984) at MERL. Computer simulation experiments aided the description of the basic physical, chemical, and biological processes occurring in these controlled ecosystem experiments. The measured parameters defining the physical and biological transport system, such as concentration $(C p)$, flux $(F p)$, and settling velocity $(V p)$ of particles, thickness of the equivalent stagnant boundary film (=diffusive sublayer) across which ions would have to move by molecular diffusion to be taken up by surface sediments, bioturbation rate, and the amounts taken up by walls $(=0)$, were the same as those taken by Santschi et al. (1986) for ELA and Santschi et al. (1987) and Nyffeler et al. (1986) for MERL, under similar conditions. The chemical properties are given by a forward $\left(k_{1}\right)$ and backward $\left(k_{-1}\right)$ rate constant for scavenging (=adsorption + coagulation + incorporation) reactions of radio- 
nuclides onto suspended and settled particles. The distribution ratio between particles and water at equilibrium, $K_{D}{ }^{\infty}$, is related to the kinetic constants by $K_{D}^{\infty}=k_{1} / k_{-1}$ and to the fraction associated with filterable particles, $f p$, by $K_{D}=f p(1-f p)^{-1} C p^{-1}$. The constants are thus taken from Santschi et al. (1987) and Nyffeler et al. (1984, 1986) and are used to predict uptake by the sediment or are adjusted for the water-column processes to simultaneously simulate the removal curve $\left(C / C_{0}\right)$ and uptake by suspended plankton (see shaded curves in Figs. 2-5) using the numerical transport model of Nyffeler et al. (1986).

Cobalt-Co is an element essential for the growth of some phytoplankton via bacterially synthesized vitamin $B_{12}$ (Provasoli 1969). It might therefore be expccted to show some nutrient-type behavior. Conversely, it can behave similarly to $\mathrm{Mn}$ in the ocean (Knauer et al. 1982) as its binding to man-

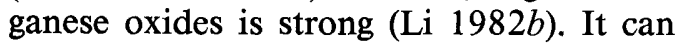
exist in two oxidation states-II and IIIwith valence state II being the thermodynamically stable form (Stumm and Morgan 1981). On Mn-oxide surfaces, Co(II) is oxidized to Co(III) (Dillard et al. 1982). In surface and subsurface continental waters, radiocobalt has often been found associated with dissolved organic carbon (Nishiwaki et al. 1981; Killey et al. 1984). Its concentration in natural waters is low: $0.2 \mu \mathrm{g} \mathrm{liter}^{-1}$ in freshwaters (Martin and Meybeck 1979) and $\leq 0.006 \mu \mathrm{g} \mathrm{liter}^{-1}$ in the ocean (Bruland 1983). In both freshwater and seawater enclosures, a large percentage of Co tracer was previously found to be extractable by activated charcoal, indicating associations with organic carbon molecules (e.g. Amdurer et al. 1983; Santschi et al. 1987; Hesslein et al. 1980; Schindler et al. 1980). However, its removal behavior often resembled that of $\mathrm{Mn}$.

Co was added to the ELA enclosures as ${ }^{60} \mathrm{Co}^{2+},{ }^{57} \mathrm{Co}^{3+}$, and ${ }^{58} \mathrm{Co}$ (II) humic acid complex. In Fig. 2, the removal curves of selected forms of Co nuclides are compared for different enclosures at ELA and in the MERL tanks. The fraction of each nuclide absorbed to suspended particles is compared to that expected from laboratory-scale uptake experiments of radiotracers on sur- face sediments. The curves drawn are the optimized model fits to the data using the approach described above. It is important to note that in many cases, distribution coefficients $\left(K_{D}\right)$ determined experimentally in separate experiments on sediment particles or used to model-fit the data are considerably lower than those on plankton, indicating stronger uptake by plankton than by sediments. Also, diagenetic release of the tracers in the sediments is indicated by some model fits, which require lower $K_{D}$ values in sediments. Several noteworthy observations can be made from the ELA data.

${ }^{58} \mathrm{Co}$ (II) attached to humic acids and added to the tanks $4 \mathrm{~d}$ later is removed at the same rate as ${ }^{60} \mathrm{Co}^{2+}$, but released from sediments of tube 2 (after lowering the $\mathrm{pH}$ to 4.8$)$ to a considerably higher extent $(60 \%$ rather than 23\%). This can be calculated from the ratio of the relative concentrations in the water column $\left(C / C_{0}\right)$ after acid addition, relative to the amount removed to the sediments before the $\mathrm{pH}$ was lowered (1 $-C_{\min } / C_{0}$, in Fig. 2A). This implies that the Co-humic acid complex is strong enough to survive in the sediments for a few weeks, but labile enough to dissociate at the lowered $\mathrm{pH} .{ }^{60} \mathrm{Co}$ and ${ }^{58} \mathrm{Co}$ do not interchange in the water or in the sediments. Under natural conditions, however, there is often not enough humic acid in the water to affect the Co pathways to such a large extent. ${ }^{60} \mathrm{Co}$ (II) is released from sediments of tubes 1 and 2 (Fig. 2A) at a much lower rate than from settled plankton in tube 13 (Fig. 2B), indicating irreversible fixation in the sediments after settling, possibly due to attachment to iron and manganese hydroxides ( $\mathrm{Li} \mathrm{1982b}$ ) or due to insoluble sulfide formation. ${ }^{57} \mathrm{Co}$ (III) is removed and released at the same rate as ${ }^{60} \mathrm{Co}$ (II) in enclosures with sediments (tubes 1 and 3, Fig. 2A), but behaves differently from ${ }^{60} \mathrm{Co}$ (II) in enclosures without sediments (tube 13, Fig. 2B). Only $60 \%$ of Co(II) was released in tubes with sediments rather than almost $100 \%$ in tubes without sediments after lowering the $\mathrm{pH}$ to 4.8 . This probably indicates that natural Co traced by ${ }^{60} \mathrm{Co}(\mathrm{II})$ is not sorbed and cycled as its oxidation product $\mathrm{Co}(\mathrm{III})$. This directly contradicts the postulation of Jackson et al. (1980). 
ELA

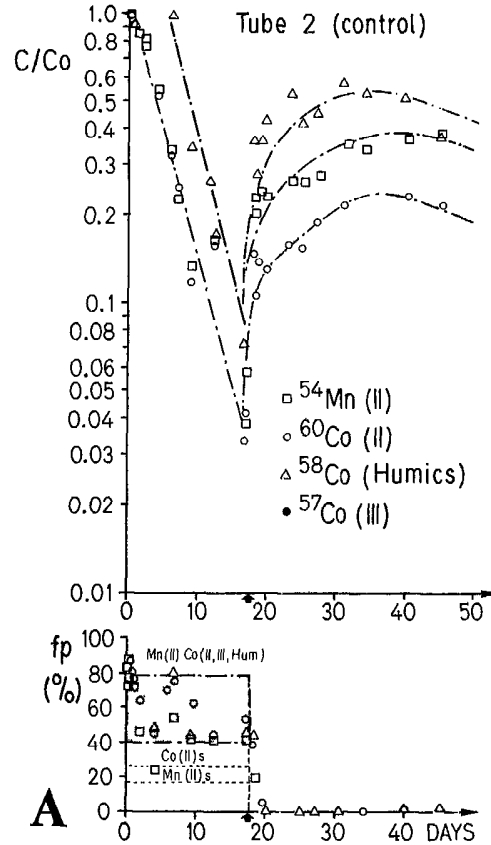

ELA

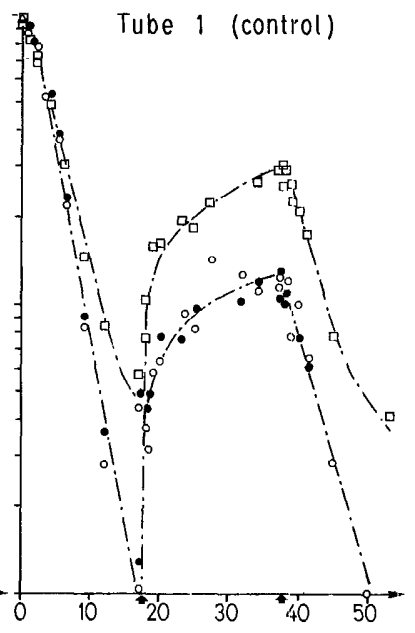

ELA

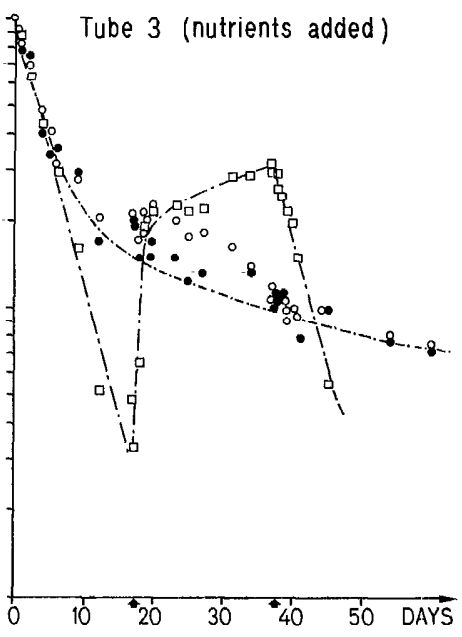

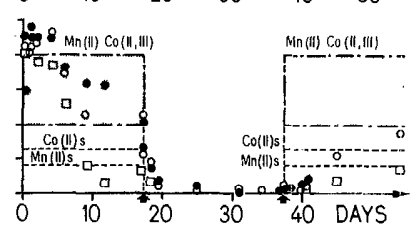
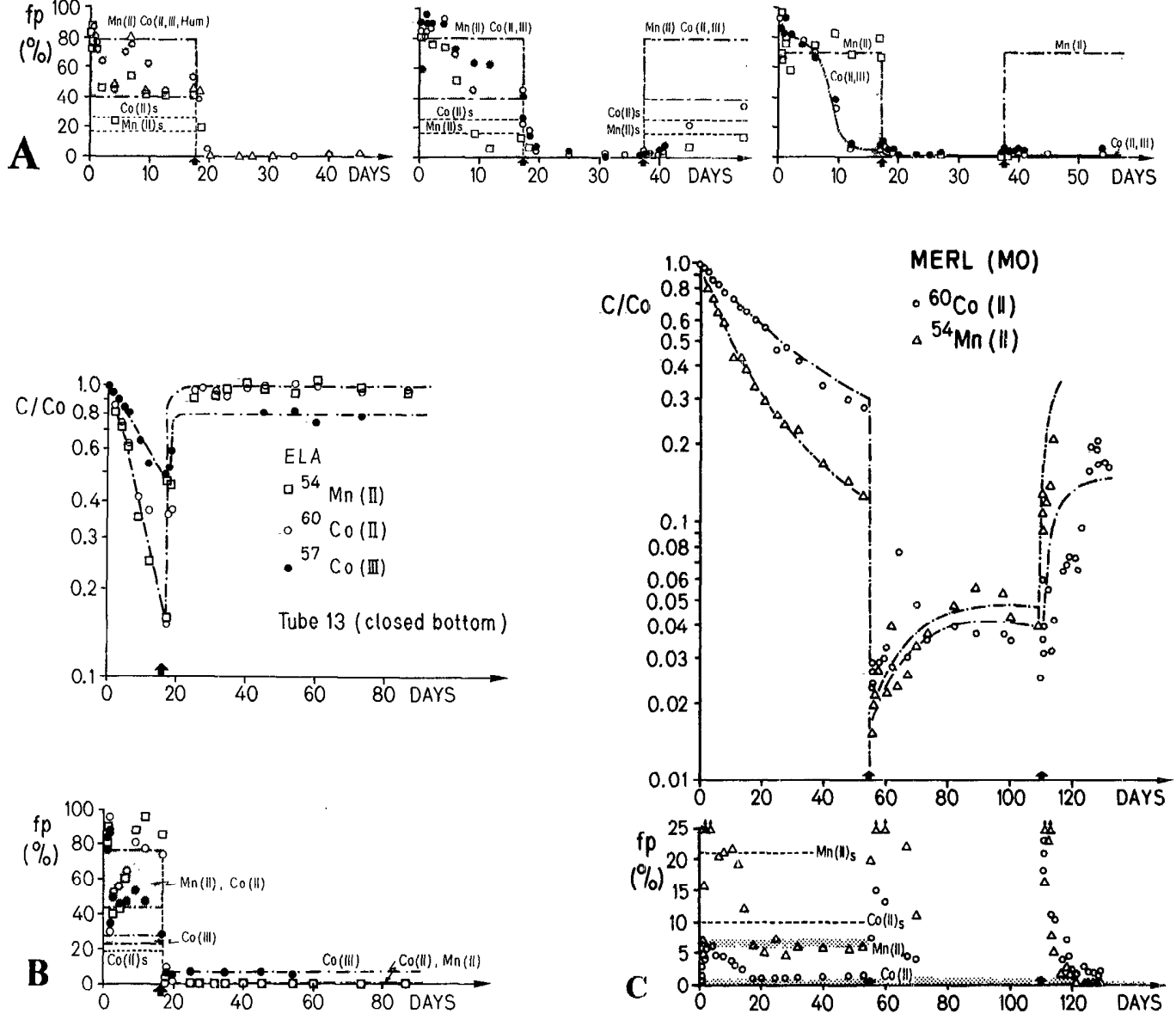

Fig. 2. A, B. Removal from the water column of various Co isotopes in different chemical forms is shown as the fraction remaining $\left(C / C_{0}\right.$, above) as well as the fraction adsorbed to suspended particles of planktonic origin ( $f p$, below), as a function of time. ${ }^{54} \mathrm{Mn}$ is shown for comparison, as $\mathrm{Mn}$ and Co are often cycled through the sediment-water system in similar ways. The relative involvement in plankton-based pathways (e.g. active 
In general, there is a strong similarity between Co and $\mathrm{Mn}$ in the shape of the removal curve and the response to acid addition. However, in the enclosure that received the added nutrients (tube 3 , Fig. 2A), cycling of $\mathrm{Co}$ (II) was completely decoupled from that of $\mathrm{Mn}$ (II), i.e. Co was not released from sediments after acid addition. Furthermore, Co was removed considerably more slowly throughout the experiment, indicating a slower turnover of Co within the system. In this eutrophic system, turnover rates of organic carbon and associated elements could have been significantly lower. The vertical flux of particulate organic carbon to the sediments, as measured in sediment traps, was enhanced by $50-100 \%$ as compared with that in the control tubes 1 and 2, but the biomass, as measured by chlorophyll $a$ concentrations, was at least an order of magnitude higher (44 vs. $3 \mu \mathrm{g} \mathrm{liter}^{-1}$ : Santschi et al. 1986). However, particle concentrations by weight were similiar in all three tubes, indicating that living biomass did not comprise the major fraction of the particle mass in the control tubes. In the cutrophied tube 3, this was probably not true, as typical ratios of total carbon to $\mathrm{Chl} a$ in freshwater ecosystems are of the order of 100 , thus suggesting living plankton was the major component of the suspended particles. Turnover rates of the living biomass in tube 3 could therefore have been significantly lower despite similar overall particle residence times in both eutrophied and control systems. If $\mathrm{Co}$ (II) was taken up preferentially by living plankton in tube 3 , it would have been removed at a lower rate than in the other two tubes.

As a result of this situation, the bacterial biomass in tube 3 could have been also greatly enhanced, thus creating a larger demand for Co synthesis into vitamin $B_{12}$. This could easily have created a scarcity of $\mathrm{Co}^{2+}$ and a more efficient uptake of all forms of Co. Indeed, turnover rates of vitamin $B_{12}$ under similar conditions have been reported as 1-2 d in field studies (Sorokin 1971). Alternatively, Co could have been complexed by amino acids (Nishiwaki et al. 1981). This example illustrates the close coupling of biological, chemical, sedimentological, and physical processes in freshwater ecosystems and the predominance of certain chemical species, which would not have been predicted from laboratory experiments alone but could be identified with radiotracer methods. The tentative explanations put forth here need further testing.

In the marine ecosystems of MERL, Co(II) behavior is more closely linked to that of Mn than to that of any other element tested, even though $\mathrm{Mn}$ is more rapidly cycled than Co. Under anoxic conditions in the water and sediments, both elements are released from the newly anoxic sediments though more Co than $\mathrm{Mn}$ was retained in the sediments (Fig. 2C).

From these results one would predict oceanic residence times of Co of the same order of magnitude as those for $\mathrm{Mn}$, which are 50-1,000 yr, depending on the ocean basin and method of calculation (e.g. Brewer 1975; Brewer et al. 1980; Li 1982a; Col-

uptake and regeneration, e.g. as vitamin $B_{12}$ ) vs. scdiment-based pathways (e.g. immobilization in sulfidic phases) was tested by adding two- and three-valent (by $\mathrm{H}_{2} \mathrm{O}_{2}$ oxidation) and humic-acid-bound cobalt. Tube 13 (panel B) did not contain any scdiments on the bottom. Arrows depict, in ELA enclosures, the time of adjustment of the $\mathrm{pH}$ from 6.5 to 4.8 by adding $\mathrm{HCl}$ (1 st arrow) and back to $\mathrm{pH} 6.5$ by adding $\mathrm{CaCO}_{3}$ (2nd arrow).

C. In the MERL tanks the first arrow depicts the time of replacement of the overlying water column with new seawater. The second arrow depicts the beginning of an anoxic water column experiment (by preventing gas exchange of the remaining $10 \%$ of the water column through airtight coverage). The dashed lines in the upper panel indicate model simulations of the radiotracer removal curves based on measured parameters in the tanks [particle flux and concentration, radiotracer uptake on suspended particles, thickness of the equivalent stagnant boundary layer (diffusive sublayer), and particle mixing ratc] and in the lab (extent and kinetics of radiotracer uptake on surface sediments). Shaded areas in the lower panel are the range of values for the fractions on particles $(f p)$ used to model the removal curves $\left(C / C_{0}\right)$; the dashed curves in the lower part indicate the $f p$ expected from laboratory-scale uptake experiments of radioactive tracers on surface sediments. Due to resuspension of fine particles later in the MERL experiments, the shaded areas do not always correspond to measured values of $\int p$. 
lier and Edmond 1984). For lakes, residence times of Co could be quite different from those of $\mathrm{Mn}$, as was shown above.

Mercury and silver $-\mathrm{Hg}$ (II) and $\mathrm{Ag}(\mathrm{I})$ were added in only one chemical form-the aqueous ion. According to thermodynamic predictions (Stumm and Morgan 1981), both elements should be present as the $\mathrm{Cl}^{-}$complex in seawater $\left(\mathrm{AgCl}_{2}{ }^{-}\right.$and $\left.\mathrm{HgCl}_{4}{ }^{2-}\right)$ and as chloride or hydroxy complex in freshwater $\left[\mathrm{AgCl}^{0}, \mathrm{Ag}^{+}, \mathrm{Hg}(\mathrm{OH})_{2}, \mathrm{HgOHCl}\right]$. In addition, the humic acid complex of $\mathrm{Hg}$ (II) is very stable (Kerndorf and Schnitzer 1980) probably due to binding to sulfhydryl functional groups. Both $\mathrm{Hg}$ and $\mathrm{Ag}$ penetrate cell membranes more easily as the neutral chloro-complex (Engel et al. 1981; Gutknecht 1981).

Mercury concentrations in ocean and freshwater environments are 1-10 pM (Bruland 1983) and about $300 \mathrm{pM}$ (Li 1982a), respectively. Turner and Rudd (1983) determined $100 \mathrm{pM}$ for total $\mathrm{Hg}$, and about 7 pM for methylated $\mathrm{Hg}$ in Clay Lake (Wabigoon River system) in northwest Ontario, close to the ELA lakes. In both seawater and freshwater enclosures, a large fraction of ${ }^{203} \mathrm{Hg}$ was extractable by activated charcoal or ultrafiltrable (Hesslein et al. 1980; Amdurer et al. 1983; Santschi et al. 1987), indicating associations to "dissolved" organic carbon molecules.

Silver concentrations in ocean and freshwater environments are about $1 \mathrm{pM}$ (Bruland 1983) and $2 \mathrm{nM}$ (Li 1982a) respectively. Considerably less is known about the biogeochemical behavior of $\mathrm{Ag}$ in both freshwater and seawater systems. In the ocean, the distribution of $\mathrm{Ag}(\mathrm{I})$ appears to follow that of $\mathrm{Cu}$ (Martin et al. 1983).

The strong binding to humic and fulvic acids could explain the general insensitivity of the removal of both isotopes in the ELA enclosures to $\mathrm{pH}$ change (Fig. 3A, B). Uptake of both elements by biogenic particles, humic and fulvic acids, possibly onto sulfhydryl groups, would become insensitive to a $\mathrm{pH}$ variation from 7 to 5 . Adsorption edges of $\mathrm{Hg}$ and humic acids, for example, are well below pH 5 (Kerndorf and Schnitzer 1980). Furthermore, both $\mathrm{Hg}$ and $\mathrm{Ag}$ not only form stable complexes with humic and fulvic acids in freshwater environ- ments (Kerndorf and Schnitzer 1980; Whitlow and Rice 1985) but can also be reduced to the elemental state by these acids (Alberts et al. 1974) or to alkylated forms by bacteria (Wood and Wang 1985). However, since these latter forms would stay in solution, they could not have been important here since both nuclides associated with suspended particles in the water column to a much higher degree than would have been predicted from laboratory uptake experiments with surface sediments.

In the MERL tanks, ${ }^{203} \mathrm{Hg}$ behaved strongly "particle-reactive" (Fig. 3C), but its "dissolved" fraction was found predominantly in the colloidal organic carbon group (Santschi et al. 1987). The extent of adsorption of ${ }^{203} \mathrm{Hg}$ onto suspended particles in seawater can be strongly influenced by the concentration of DOC ( $\mathrm{Li}$ et al. 1984; Santschi et al. 1980c) and was also found to be a function of the POC contents of sediment particles (Buchholtz et al. 1986). There was no noticeable effect of anoxia on the behavior of $\mathrm{Hg}$. The increased particle associations at the beginning of the anoxia cxperiment (2nd arrow, Fig. 3C) were probably caused by resuspension of surface sediment.

In both marine and lacustrine ecosystems, $\mathrm{Hg}$ and $\mathrm{Ag}$ were strongly associated with biogenic particles and organic macromolecules. This association was robust enough that lowering the $\mathrm{pH}$ to 4.8 in freshwater and a short-term anoxic event did not noticeably change the relative amounts of these nuclides associated with particles.

Selenium - Se was added in two different oxidation states: as $\mathrm{Se}(\mathrm{IV})$ to one MERL tank and as $\mathrm{Se}(\mathrm{VI})$ to another. (Amdurer 1983; Santschi et al. 1987). The thermodynamically stable oxidation state would be expected to be Se(VI) (Measures et al. 1980).

Selenium is found in the deep ocean predominantly as $\mathrm{SeO}_{4}{ }^{2--}$. However, the reduced forms of the $\mathrm{Se}, \mathrm{ScO}_{3}{ }^{2-}$, clemental $\left(\mathrm{Se}^{0}\right)$ or organically bound forms (e.g. Seamino acids or peptides) have been shown to be of major importance in "regenerative" environments, i.e. environments where organic carbon is degraded rather than synthesized (Cutter and Bruland 1984; Takayanagi and Wong 1985). Se speciation and 
Trace element cycles
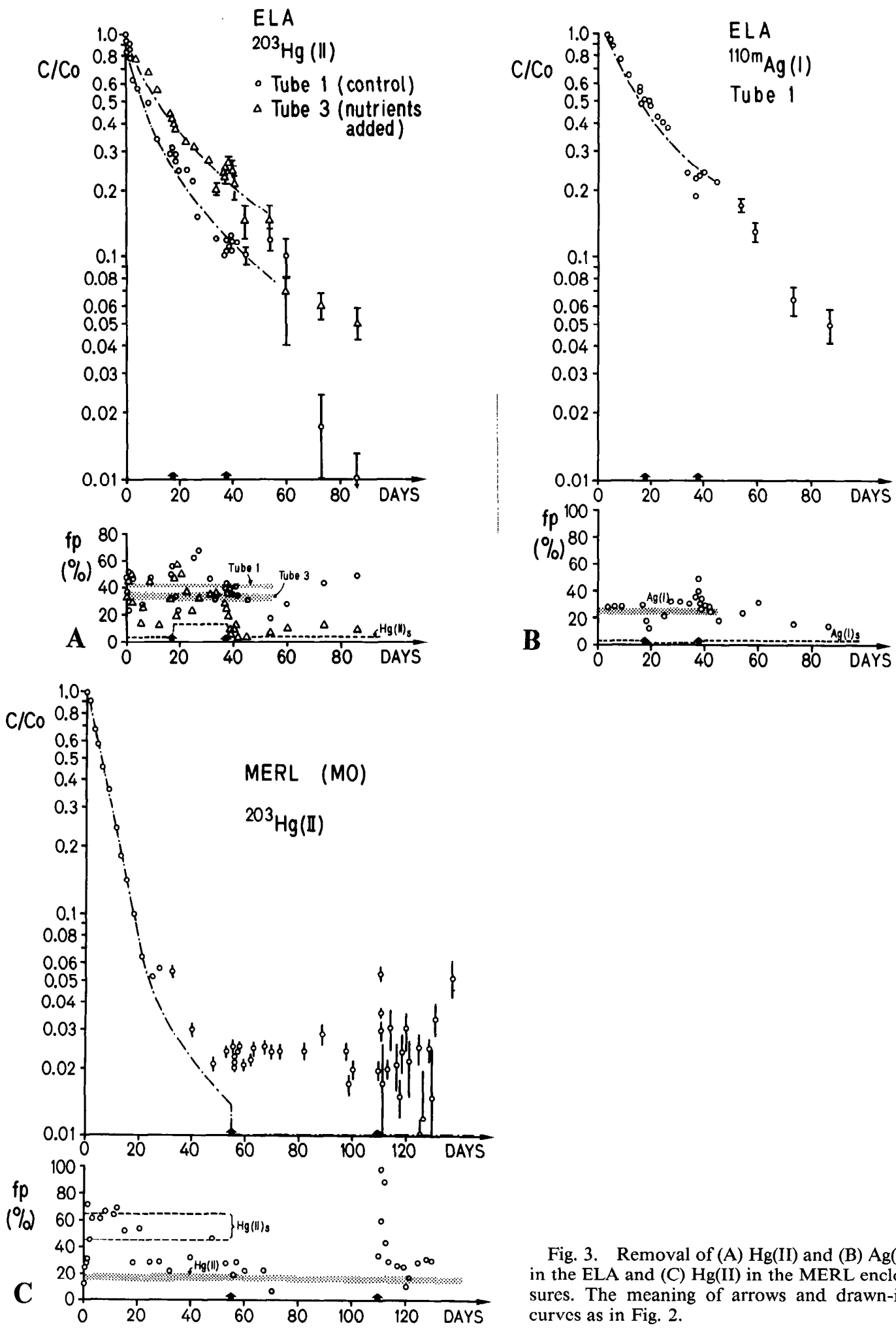

Fig. 3. Removal of (A) $\mathrm{Hg}(\mathrm{II})$ and (B) $\mathrm{Ag}(\mathrm{I})$ in the ELA and (C) $\mathrm{Hg}(\mathrm{II})$ in the MERL enclosures. The meaning of arrows and drawn-in curves as in Fig. 2. 

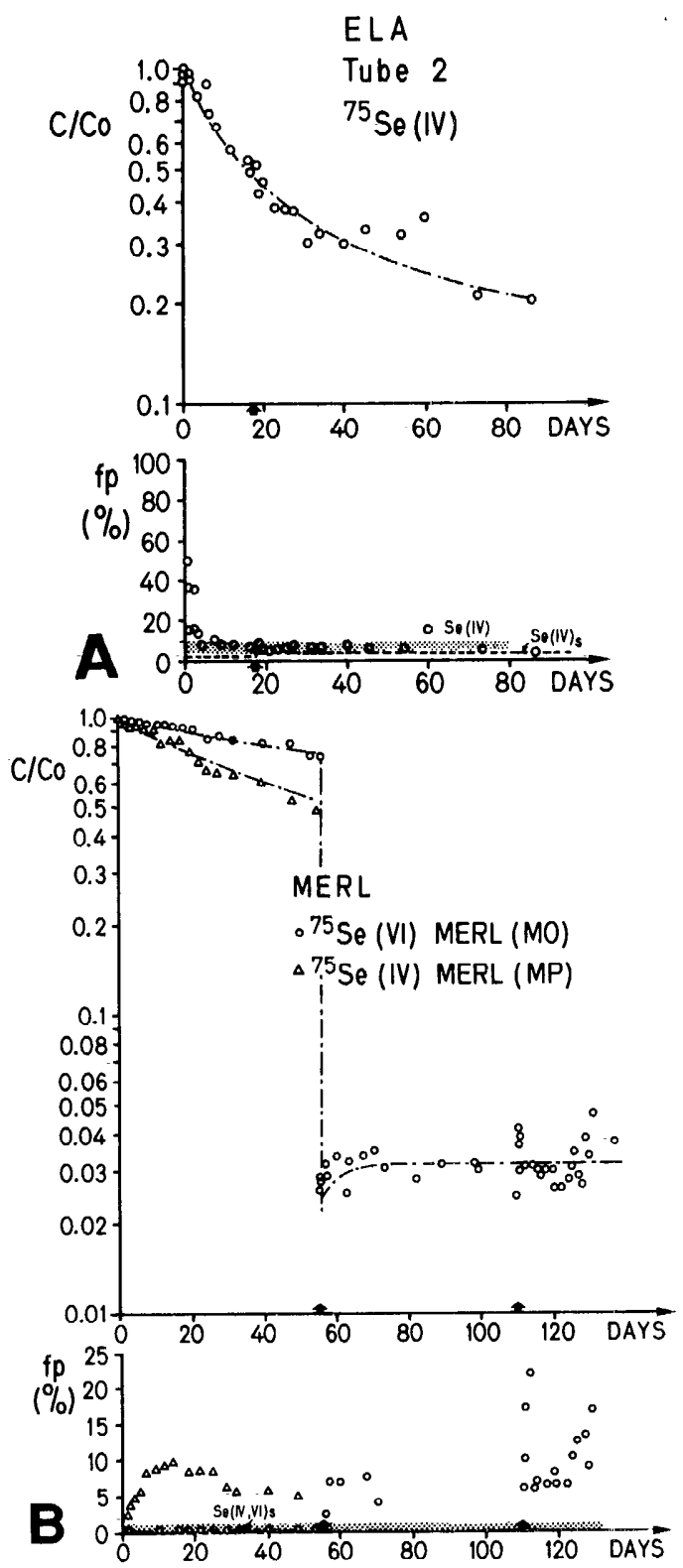

Fig. 4. Removal of Se isotopes in (A) the ELA and (B) the MERL enclosures. The meaning of arrows and drawn-in curves as in Fig. 2.

removal rates in the open ocean appear to be partially controlled by primary productivity (Measures and Burton 1980). Selenium concentrations in ocean and freshwater environments are about $1 \mathrm{nM}$ (Bruland 1983; Li 1982a). Hesslein et al. (1980),
Amdurer et al. (1983), and Santschi et al. (1987) reported that a significant fraction of ${ }^{75} \mathrm{Se}$ (IV) added to enclosed ecosystems becomes extractable by charcoal alone in both sea- and freshwater enclosures at ambient concentration levels after a short period of time (e.g. days).

The data in Fig. 4B are consistent with a reductive uptake of $\mathrm{Se}$ (IV and VI) into the plankton biomass of the MERL tanks. A considerably greater percentage is found associated with suspended particles than expected from sorption experiments with surface sediment, and a slow but steady conversion of both oxidized forms into a charcoal- and (XAD-) extractable colloidal organic form, which was also ultrafiltrable (Amdurer 1983; Santschi et al. 1987), was observed, reaching $25-65 \%$ and $3 \%$ of the total amounts of $\mathrm{Se}(\mathrm{IV})$ or $\mathrm{Se}(\mathrm{VI})$, respectively, after $32 \mathrm{~d}$.

From this initial rate of increase of the charcoal-extractable form, and assuming a first-order reduction reaction for the noncharcoal-extractable $\mathrm{SeO}_{3}{ }^{2-}$ and $\mathrm{SeO}_{4}{ }^{2-}$ anions, a residence time ( $=$ inverse of first-order reaction rate constant) for the slow reductive incorporation of Se into the organic biomass and its subsequent fast release as charcoal-extractable dissolved organic or elemental Se could be calculated. Residence times of $30-100 \mathrm{~d}$ and $\sim 10^{3} \mathrm{~d}$ for the reduction of $\mathrm{SeO}_{3}{ }^{2-}$ and $\mathrm{SeO}_{4}{ }^{2-}$, respectively, could be estimated for coastal marine environments (Santschi et al. 1987). This is in accordance with estimates by Cutter and Bruland (1984) for the productive equatorial upwelling regime of the eastern Pacific with similarly high primary production and regeneration rates. According to Cutter and Bruland, the release of organically bound Se from the biomass is the fastest reaction (with a characteristic time of $\leq 5 \mathrm{~d}$ ), while the rate-controlling process appears to be the reductive incorporation of $\mathrm{Se}$ into the biomass. Initiation of anoxia in the MERL tanks appeared to increase the particle association of Se initially present as $\mathrm{Se}(\mathrm{VI})$, most likely indicating accelerated reduction of Se.

In the ELA enclosures (Fig. 4A), Se(IV) was taken up more quickly by plankton in 
the first $17 \mathrm{~d}$ of the experiment, but thereafter was not much removed from the system: no change was observed in Se behavior during and after the $\mathrm{pH}$ transient. This would also indicate that its fate was not controlled by its simple adsorption behavior onto suspended or settled particles, which would result in an enhanced sorption at lower $\mathrm{pH}$ (Stumm and Morgan 1981). Some $\mathrm{pH}$ independent biological factors are suggested.

In both seawater and freshwater ecosystems, biological factors appeared to influence strongly the particle associations and removal rates of these nuclides to sediments. Although in the freshwater ecosystem particle associations and removal behavior of Se could have been predicted from sorption experiments to surface sediments, Se was taken up by biogenic particles of the marine water column to a considerably greater extent than predicted by sediment uptake experiments in the laboratory. In both systems, a reductive uptake by plankton would explain the robustness of the particle associations to a perturbation of the ecosystem structure and function by acidification or asphyxiation.

Chromium - Cr was added in two different oxidation states to ELA and MERL enclosures: $\mathrm{Cr}$ (III) and $\mathrm{Cr}$ (IV). The stable oxidation state of chromium under the redox and $\mathrm{pH}$ conditions of both ELA and MERL systems is $\mathrm{Cr}$ (VI) (Goldschmidt 1954; Elderfield 1970; Cranston and Murray 1978). In Fig. 5B, Cr(VI) is shown to be removed much more slowly in the MERL tanks than $\mathrm{Cr}(\mathrm{III})$. From the conversion of the kinetically robust complex of aqueous $\mathrm{Cr}$ (III) (Stumm and Morgan 1981) to Cr(VI) in the MERL tanks, Amdurer (1983) calculated an oxidation residence time of 17-100 d. This residence time is close to that for the exchange of water molecules of the hydrated Cr(III) ion (Taube 1968). Amdurer (1983) found that the first-order oxidation rate constant strongly correlates with the particle flux, which is coupled to the resuspension rate and thus to the bioturbation rate in the system (Santschi et al. 1980b, 1982, 1983; Rhoads et al. 1978). Thus, the Cr(III) oxidation rate becomes controlled by the re- cycling rate of particles through the sediment-water interface rather than simply by the quantity and quality of suspended particles in the water column.

$\mathrm{Cr}$ (III) is removed faster than $\mathrm{Cr}(\mathrm{VI})$ in the ELA enclosures (Fig. 5A) as well. Also, $\mathrm{Cr}$ (VI) removal is not affected by increased living biomass and particle flux (tube 3 vs. tube 2). The fractions of $\mathrm{Cr}$ (III) and $\mathrm{Cr}$ (VI) associated with suspended particles are, however, significantly higher than predicted from sediment uptake studies $\left(\mathrm{Cr}_{s}\right.$, Fig. 5A). A possible role of dissolved organic carbon (DOC) in the photoreduction of the weakly sorbing $\mathrm{Cr}(\mathrm{VI})$ anion to the "particle-reactive" Cr(III) cation was suggested by Riedel (1985). The considerably greater removal rates of $\mathrm{Cr}(\mathrm{VI})$ than expected from laboratory sorption studies could thus be caused by such a process since a large fraction of dissolved constituents in ELA waters consists of DOC.

In marine ecosystems $\mathrm{Cr}$ (III) was oxidized relatively rapidly to the soluble $\mathrm{Cr}$ (VI) anion, a process mediated by the resuspended particle flux, but in freshwater ecosystems $\mathrm{Cr}$ (VI) was associated with biogenic particles to a much higher degree than predicted. This may indicate photoreduction of the weakly sorbing $\mathrm{Cr}(\mathrm{VI})$ anion to the "particle-reactive" Cr(III) cation, mediated by DOC.

\section{Summary and conclusions}

These experiments illustrate both the basic strengths and weaknesses of whole ecosystem experimentation using radiotracers. Taken at face value, the data illustrate the close coupling of interrelated biological (e.g. primary production for $\mathrm{Co}$, Se nuclides), chemical (e.g. pH and redox potential for $\mathrm{Mn}$ and Co nuclides), sedimentary (e.g. sedimentation and resuspension for $\mathrm{Cr}$ nuclides), and physical (e.g. turbulence-controlled laminar benthic boundary sublayer for all nuclides in dissolved form) processes, and biochemical processes on particle surfaces which control the prevalent chemical species and their conversion kinetics into one another. Depending on the particular environment and conditions, trace elements can show dramatic differences in behavior. 

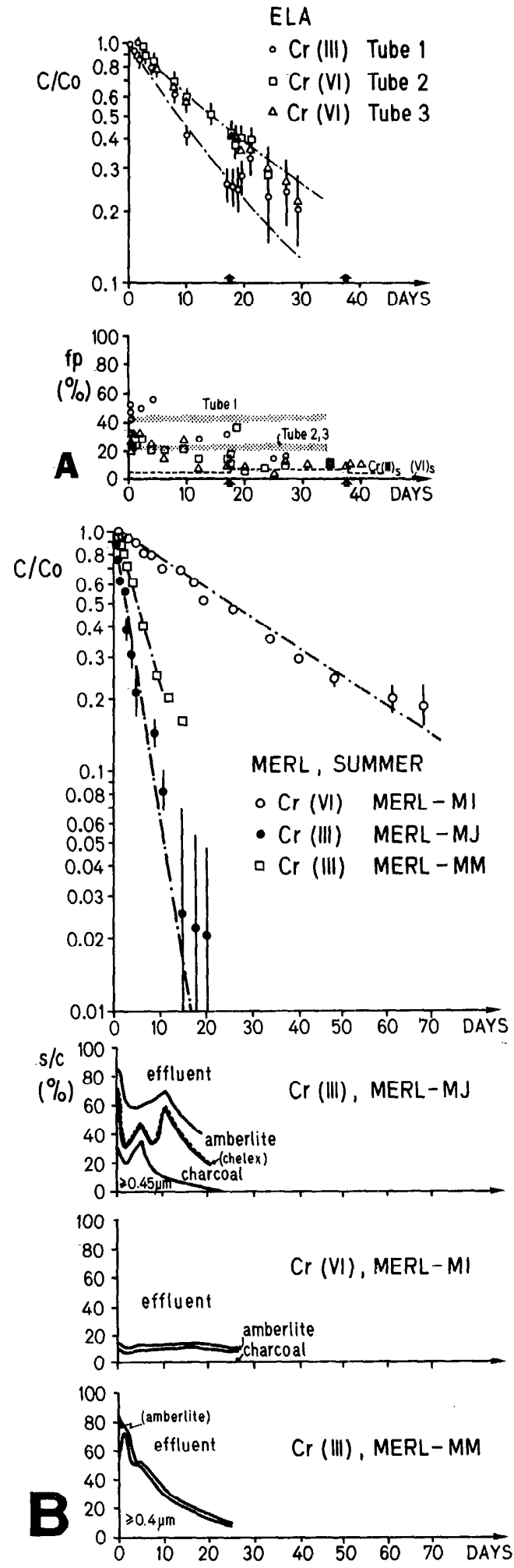

The chemical forms identified in these ecosystem experiments would not have been predicted from thermodynamic considerations alone. All five elements (e.g. $\mathrm{Co}, \mathrm{Hg}$, $\mathrm{Ag}, \mathrm{Se}, \mathrm{Cr}$ ) showed behavior that indicated an indirect involvement of the carbon cycle, in addition to the direct influence of the cycling of $\mathrm{Mn}$ and $\mathrm{Fe}$ within the ecosystem.

The removal to particles and sediments and the back-diffusion of "redox-sensitive" trace elements as revealed by the redox (MERL) and acid-base (ELA) titrations carried out as perturbations of whole ecosystems can be summarized as follows. Generally, there is a strong similarity in the behavior of $\mathrm{Co}$ (II) and $\mathrm{Mn}$ (II) in freshwater (ELA) and marine (MERL) ecosystems. This is demonstrated by similar removal and back-diffusion rates after changes of $\mathrm{pH}$ and $\mathrm{pE}$. Such behavior would suggest Mn oxide phases as the controlling factors. In eutrophied ecosystems at ELA, however, Co(II) was removed at considerably slower rates than $\mathrm{Mn}(\mathrm{II})$ and was little affected by $\mathrm{pH}$ changes, suggesting different binding sites for $\mathrm{Co}$, possibly those of vitamin $\mathrm{B}_{12}$. Co cycling also depended on the chemical form of Co added to the system (II, III, or bound to humic acids). Strong organic complexation was suggested by the insensitivity of the removal rates of $\mathrm{Hg}$ and $\mathrm{Ag}$ to perturbations in $\mathrm{pH}$ (ELA) and $\mathrm{pE}$ (MERL), and by significant associations with colloidal organic matter. Both $\mathrm{Se}(\mathrm{IV})$ and $\mathrm{Se}(\mathrm{VI})$ yielded organically associated species in fresh-

Fig. 5. Removal of $\mathrm{Cr}$ isotopes in the (A) ELA and (B) MERL enclosures. The latter data are from Amdurer 1983. The meaning of the arrows and drawn-in curves as in Fig. 2. $S / C$ indicates the cumulative ratio of a measured species $(S)$ to the total concentration in solution $(C)$. The sequence of the chemical speciation scheme was filter-charcoal-Chelex-Amberlite. Activated charcoal adsorbs nonpolar, high-molecular-weight organics and colloids of different kinds. Chelex-100 adsorbs mostly the inorganic forms of ionic species of transition metals, and Amberlite IRA-438 resin adsorbs mostly inorganic colloids such as colloidal silica or hydrous metal oxides or hydroxides. A reversal of the sequence charcoal-Chelex revealed that uncharged species extracted by charcoal can also be retained by Chelex resin (Amdurer ct al. 1983). No prediction about the fraction of $\mathrm{Cr}$ adsorbed to particles in the MERL ecosystems is possible due to lack of experimental data. 
water (based on insensitivity of removal rates and extent of particle uptake to changes in $\mathrm{pH}$ ) and marine ecosystems (based on the time dependence of the occurrence of charcoal-extractable species). The rates of conversion to the reduced organic form were considerably faster for Se(IV) than for $\mathrm{Se}(\mathrm{VI})$. The rapid oxidation rates of $\mathrm{Cr}$ (III) to $\mathrm{Cr}(\mathrm{VI})$ were controlled by the recycling rates of particles across the sediment-water interface in the MERL ecosystems. In the DOC-rich waters of the ELA ecosystems, $\mathrm{Cr}(\mathrm{VI})$ sorbed to plankton to a much greater extent than expected from $\mathrm{Cr}(\mathrm{VI})$ sorption tests in the laboratory, suggesting partial reduction in the water column.

For most elements (except for $\mathrm{Hg}$ at MERL), the values for a distribution ratio $\left(K_{D}\right)$ required to simulate the data were lower for the sediments and higher for the water column than derived from laboratory batch radiotracer uptake experiments with surfacc sediments. This most likely indicates that these trace elements were preferentially taken up by plankton and diagenetically released in the surface sediments. In general there were only small differences in the overall behavior of these five trace elements between shallow marine and freshwater environments, except possibly for $\mathrm{Cr}$. The significance of such experiments lies in their ability to show bioavailability and biomagnification of trace elements in aquatic ecosystems, and how trace element uptake by biogenic particles and colloidal organic matter and subsequent release by respiration and redox reactions are coupled in shallow ecosystems.

Organic matter as humic and fulvic acids dissolved in natural waters can affect sorption rates of trace metals to suspended matter and the coagulation rates of microparticulates. Organic matter can also mediate redox reactions alone or in concert with natural sunlight, causing a complex behavior for various trace elements in aquatic systems. This ability of DOC must have affected the behavior of the radioactive trace metals added to thesc aquatic ecosystems in a complex way not amenable to any straightforward proof on a molecular level. However, the results of these tracer experiments show that a relative lack of insight into mechanistic detail on the molecular level can be compensated by a gain in ecological relevance. Valuable hypotheses evolved from such controlled ecosystem experiments, which will need further testing in less complex environments.

\section{References}

Adler, D., M. Amdurer, AND P. H. Santschi. 1980. Metal tracers in two marine microcosms: Sensitivity to scale and configuration, p. 348-368. In Microcosms in ecological research. CONF-781101. NTIS.

Ahrland, S., J. Chatt, ANd N. R. Davies. 1958. The relative affinities of ligand atoms for acceptor molecules and ions. Q. Rev. Chem. Soc. 12: 265-276.

Alberts, J. J., J. E. SCHINDler, R. W. Müll.er, AND D. E. NutTer. 1974. Elemental mercury evolution mediated by humic acid. Science 184: 895897.

Aller, R. C. 1980. Diagenetic processes near the sediment-water interface of Long Island Sound. 2. Fe and Mn. Adv. Geophys. 22: 351-415.

AMDURER, M. 1983. Chemical speciation and cycling of trace elements in estuarics: Radiotracer studies in marine microcosms. Ph.D. thesis, Columbia Univ.

- D. Adler, And P. H. Santschi. 1982. The use of radiotracers in studies of trace metal bchavior in mesocosms: Advantages and limitations, p. 81-95. In G. D. Grice [ed.], Marine mesocosms: Biological and chemical research in experimental ecosystems. Springer.

,-- AND - 1983. Studies of chemical forms of trace elements in sea water using radiotracers, p. 537-562. In Trace metals in sea water. NATO Conf. Ser. 4: Mar. Sci. V. 9. Plenum.

ANDERS, A. W., AND R. C. HARRIZ. 1975. Observations on the association between mercury and organic matter dissolved in natural waters. Geochim. Cosmochim. Acta 39: 1253-1257.

ANDERSon, R. F., P. H. SANTSChI, U. P. NyfFEler, AND S. L. SCHIFF. 1987. Validating the use of radiotracers as analogues of stable metal behavior in enclosed aquatic ecosystem experiments. Can. J. Fish. Aquat. Sci. 44(suppl. 1): 251-259.

BERNER, R. A. 1984. Sedimentary pyrite formation: An update. Geochim. Cosmochim. Acta 48: 605615.

Bopp, R., P. H. SANTSChI, Y.-H. LI, AND B. L. DeCK. 1981. Biodegradation and gas exchange of gaseous alkanes in model estuarine ccosystcms. Org. Geochem. 3: 9-14.

Brewer, P. G. 1975. Minor elements in sea water, p. 415-496. In J. P. Riley and G. Skirrow [eds.], Chemical oceanography, 2nd ed. V. 2. Academic. -, Y. Nozaki, D. W. Spencer, and A. P. Fleer. 1980. Sediment trap experiments in the deep North Atlantic: Isotopic and element flux. J. Mar. Res. 38: 703-728.

BRULAND, K. W. 1983. Trace elements in sea water, p. 157-221. In J. P. Riley and R. Chester [eds.], Chemical oceanography, V. 8. Academic. 
Buchholtz, M., P. H. SANTSChI, AND W. S. Broecker. 1986. Comparison of radiotracer $\mathrm{K}_{\mathrm{D}}$-values by batch equilibration experiments with in situ determinations in the deep-sea using the MANOP Lander: The importance of geochemical mechanisms in controlling ion uptake and migration, $p$. 192-205. In T. H. Sibley and C. Myttenaire [eds.], Application of distribution coefficients to radiological assessment models. Elsevier.

BUfFLE, J. 1984. Natural organic matter and metalorganic interactions in aquatic systems, p. 165222. In H. Siegel [ed.], Metal ions in biological systems. 18. Dekker.

Collier, R., AND J. Edmond. 1984. The trace element geochemistry of marine biogenic/particulate matter. Prog. Oceanog. 13: 113-199.

Cranston, R. E., and J. W. Murray. 1978. The determination of chromium species in natural waters. Anal. Chim. Acta 99: 275-282.

Cutter, G. A., AND K. W. Bruland. 1984. The marine biogeochemistry of selenium: A re-evaluation. Limnol. Oceanogr. 29: 1179-1192.

DAlziel, J. A., AND P. A. Yeats. 1985. Reactive mercury in the central North Atlantic Ocean. Mar. Chem. 15: 357-361.

DE BaAR, H. J. W., M. P. BaCon, P. G. BRewer, AND K. W. BRULAND. 1985. Rare earth elcments in the Pacific and Atlantic oceans. Geochim. Cosmochim. Acta 49: 1943-1959.

Dillard, J. G., D. L. Crowther, and J. W. Murray. 1982. The oxidation states of cobalt and selected metals in Pacific ferromanganese nodules. Geochim. Cosmochim. Acta 46: 755-759.

Elderfield, H. 1970. Chromium speciation in sea water. Earth Planet. Sci. Lett. 9: 10-16.

EMERSON, S. 1985. Organic carbon preservation in marine sediments, p. 78-88. In The carbon cycle and atmospheric $\mathrm{CO}_{2}$ : Natural variations, $\mathrm{Ar}$ chean to present. Geophys. Monogr. Am. Geophys. Union 32.

- W. S. BROECKER, AND D. W. SCHINDLER. 1973. Gas-exchange rates in a small Canadian shield lake as determined by the radon method. J. Fish. Res. Bd. Can. 30: 1475-1484.

- - R. R. CRANSTON, AND P. S. Liss. 1979. Redox species in a reducing fjord: Equilibrium and kinetic considerations. Deep-Sea Res. 26: 859-878.

-___ AND OTHERS. 1982. Environmental oxidation rate of manganese (II): Bacterial catalysis. Gcochim. Cosmochim. Acta 46: 1073-1079.

ENGel, D. W., W. G. Sunda, AND B. A. Fowler. 1981. Factors affecting trace metal uptake and toxicity to estuarine organisms. 1. Environmental parameters, p. 127-144. In F. J. Vernberg et al. [eds.], Biological monitoring of marine pollutants. Academic.

FisHeR, N. S. 1986. On the reactivity of metals for marine phytoplankton. Limnol. Oceanogr. 31: 443449.

— M. BohÉ, AND J.-L. Teyssié. 1984. Accumulation and toxicity of $\mathrm{Cd}, \mathrm{Zn}, \mathrm{Ag}$, and $\mathrm{Hg}$ in four marine phytoplankters. Mar. Ecol, Prog. Ser. 18: $201-213$.

Gardner, W. D., K. R. Hinga, And J. Marra. 1983. Observations on the degradation of biogenic material in the deep ocean with implications on ac- curacy of sediment trap fluxes. J. Mar. Res. 41: 195-214.

Gies', J. [ED.]. 1980. Microcosms in ecological research. CONF-781101. NTIS.

GoldschmidT, V. M. 1954. Geochemistry. Oxford.

Graybeal, A., aND G. R. Heath. 1984. Remobilization of transition metals in surficial pelagic sediments from the eastern Pacific. Geochim. Cosmochim. Acta 48: 965-976.

Grice, G. D., AND M. R. Reeve [EDS.]. 1982. Marine mesocosms: Biological and chemical research in experimental ecosystems. Springer.

Grundmanis, J., aND J. W. Murray. 1982. Stoichiometry of decomposing organic matter in acrobic marine sediments. Geochim. Cosmochim. Acta 46: $1101-1121$.

GUTKNECHT, J. 1981. Inorganic mercury $\left(\mathrm{Hg}^{2+}\right)$ transport through lipid bilayer membranes. Membrane Biol. 6: 61-66.

Hesslein, R. H., W. S. Broecker, AND D. W. SCHINDLER. 1980. Fates of metal radiotracers added to a whole lake: Sediment-water interactions. Can. J. Fish. Aquat. Sci. 37: 378-386.

Hudson, J. M., AND F. M. M. Morel. 1985. The role of light and cell surfaces in the uptake of iron by phytoplankton [abstract]. Eos 46: 1266.

HuNTER, K. A., AND P. S. Liss. 1982. Organic matter and the surface charge of suspended particles in estuarine waters. Limnol. Oceanogr. 27: 322-335.

Jackson, T. A., G. Kipphut, R. H. Hesslein, AND D. W. ScHINDLER. 1980. Experimental study of trace metal chemistry in soft water lakes at different $\mathrm{pH}$ levels. Can. J. Fish. Aquat. Sci. 37: 387-402.

JøRGensen, B. B., AND N. P. RevSBech. 1985. Diffusive boundary layers and the oxygen uptake of sediments and detritus. Limnol. Oceanogr. 30: 111 122.

KeEney-KenNicutt, W. L., AND J. W. MoRse. 1985. The redox chemistry of $\mathrm{Pu}(\mathrm{V}) \mathrm{O}_{2}$ ' interaction with common mineral surfaces. Interaction in dilute solutions and sea water. Geochim. Cosmochim. Acta 49: 2577-2588.

Kerndorf, H., AND M. SCHnitzer. 1980. Sorption of metals on humic acid. Geochim. Cosmochim. Acta 44: 1701-1708.

KeSTER, D. R., R. H. BYrNe, JK., ANU Y.-J. LIANG. 1975. Redox reactions and solution complexes of iron in marine systems, p. 56-79. In T. M. Church [ed.], Marine chemistry in the coastal environment. Am Chem. Soc. Symp. Ser.

Killey, R. W., J. O. McHugh, D. R. Champ, E. L. CoOper, AND J. L. Young. 1984. Subsurface Co60 migration from a low level waste disposal site. Environ. Sci. Technol. 18: 148-157.

KING, G. M., B. C. HoweS, AND W. H. DACEy. 1985. Short-term endproducts of sulfate reduction in a salt marsh: Formation of acid volatile sulfides, elemental sulfur and pyrite. Geochim. Cosmochim. Acta 49: 1561-1566.

Knauer, G. A., J. H. Martin, And R. M. Gordon. 1982. Cobalt in north-east Pacific waters. Nature 297: 49-51.

LANGSTON, W. J., AND G. W. BRYAN. 1984. The relationships between metal speciation in the environment and bioaccumulation in aquatic organisms, p. 375-391. In C. J. M. Kramer and J. C. 
Duinker [eds.], Complexation of trace metals in natural waters. Junk.

LEPPARD, G. G. [ED.]. 1983. Trace element spcciation in surface waters and its ecological implications. NATO Conf. Ser. 1. Ecology. Plenum.

LI, Y.-H. 1982a. A brief discussion on the mean oceanic residence time of elements. Geochim. Cosmochim. Acta 46: 2671-2675.

— $1982 b$. Interelement relationship in abyssal Pacific ferromanganese nodules and associated pelagic sediments. Geochim. Cosmochim. Acta 46: 1053-1060.

- L. Burkhardt, M. Buchholtz, P. O'Hara, AND P. H. SANTSChI. 1984. Partition of radiotracers betwcen suspended particles and seawater. Geochim. Cosmochim. Acta 48: 2011-2020.

MACKenZiE, F. T., AND R. M. Garrels. 1966. Chemical mass balance between rivers and oceans. Am. J. Sci. 264: 507-525.

MaCKIN, J. E. 1986. Control of dissolved Al distributions in marine sediments by clay reconstitution reactions: Experimental evidence leading to a unified theory. Geochim. Cosmochim. Acta 50: 207214.

ㄴ 1987. Boron and silica behavior in salt-marsh sediments: Implications for palaeo-boron distributions and the early diagenesis of silica. Am. J. Sci. 287: 197-241.

Martin, J. M., G. A. Knauer, And R. M. Gordon. 1983. Silver distributions and fluxes in northeast Pacific waters. Naturc 305: 306-309.

- , AND M. MEYBECK. 1979. Elemental mass balance of material carried by world major rivers. Mar. Chem. 7: 173-206.

Measures, C. I., AND J. D. Burton. 1980. The vertical distribution and oxidation states of dissolved selenium in the N.E. Atlantic ocean and their relationship to biological processes. Earth Planet. Sci. Lett. 46: 385-396.

- AND J. M. EDMOND. 1983. The geochemical cyclc of Be: A reconnaissance. Earth Planet. Sci. Lett. 66: 101-110.

$\longrightarrow$, R. E. MCDuff, AND J. M. Edmond. 1980. Selcnium redox chemistry at the Geosecs- 1 reoccupation. Earth Planet Sci. Lett. 49: 102-108.

Moffett, J. W., AND R. G. ZiKA. 1985. Photochemistry of copper in seawater [abstract]. Eos 66: 1257.

Morgan, J. J., AND A. T. Stone. 1985. Kinctics of chemical processes of importance in lacustrine environments, p. 389-426. In W. Stumm [ed.], Chemical processes in lakes. Wiley.

Morse, J. W., AND M. Huerta-Diaz. 1985. The influence of light on the adsorption of copper from seawater onto goethite and birnessite [abstract]. Eos 66: 1257.

Murray, J. W., AND J. G. Dillard. 1979. The oxidation of cobalt (II) adsorbed on manganesc dioxidc. Gcochim. Cosmochim. Acta 43: 781-787.

in Puget Sound. Geochim. Cosmochim. Acta 42: 9-19.

Nelson, D. M., A. E. Carey, and V. T. Bowen. 1984. Plutonium oxidation state distributions in the Pacific Ocean during 1980-1981. Earth Planct. Sci. Lett. 68: $422-430$.

NishiwaKI, Y., Y. KimuRA, Y. HoNDA, AND K.
Katsurayama. 1981. Possible formation of organic cobalt complexes with amino acids and uptake by marine bivalve, p. 401-420. In Impacts of radionuclide releases into the marine environment. IAEA-SM-248. No. 128.

NYFFELER, U. P., Y.-H. LI, AND P. H. SANTSCHI. 1984. A kinctic approach to describe trace element distribution between particles and solution in natural aquatic systems. Geochim. Cosmochim. Acta 48: 1513-1522.

, P. H. SANTSCHI, AND Y.-H. Li. 1986. The relcvance of scavenging kinetics to modeling of sediment-water interactions in natural waters. Limnol. Oceanogr. 31: 277-292.

PAN-HOU, H. S., AND N. IMOURA. 1982. Involvement of mercury methylation in microbial detoxification. Arch. Microbiol. 131:176-177.

PARKER, M. 1977. Vitamin $B_{12}$ in Lake Washington, U.S.A.: Concentration and rate of uptakc. Limnol. Occanogr. 22: 527-538.

Pearson, R. G. 1969. Hard and soft acids and bases. Surv. Prog. Chem. 5: 1-52.

Provasoli, L. 1969. Algal nutrition and eutrophication, p. 574-593. In Eutrophication: Causes, consequences, correctives. Natl. Acad. Sci. Publ. 1700 .

REeBURGH, W.S. 1983. Rates of biogeochemical processes in anoxic sediments. Annu. Rev. Earth Planet. Sci. 2: 269-298.

RhoAds, D. C., J. Y. Yingst, and W. J. Ullman. 1978. Sca floor stability in central Long Island Sound. 1. Temporal changes in erodability of finegrained scdiments, p. 221-244. In M. L. Wiley [cd.], Estuarine interactions. Academic.

Riedel, G. G. 1985. Photoreduction of $\mathrm{Cr}$ (VI) in natural waters [abstract]. Eos 66: 1257.

Robbins, J. A., AND E. CALlEnder. 1975. Diagenesis of manganese in Lake Michigan sediments. Am. J. Sci. 275: 512-533.

RUTGERS VAN DER LOEFF, AND OTHERS. 1984. The asphyxiation technique: An approach to distinguishing between molecular diffusion and biologically mediated transport at the scdiment-water interface. Limnol. Occanogr. 29:675-686.

Salomons, W., AND U. Förster. 1984. Metals in the hydrocycle. Springer.

Sanchez, A. L., J. W. Murray, and T. H. Sibley. 1985. The adsorption of $\mathrm{Pu}$ IV and $\mathrm{V}$ on goethite. Geochim. Cosmochim. Acta 49: 2297-2308.

SANTSCHI, P. H. 1985. The MERL mesocosm approach for studying scdiment-water interactions and ecotoxicology. Environ. Technol. Lett. 6: 335350.

, D. Adler, M. Amdurer, Y.-H. Li, AND J. BELL. 1980a. Thorium isotopes as analogues for "particle-reactive" pollutants in coastal marine environments. Earth Planet. Sci. Lett. 47: 327335.

, S. CARSON, AND Y.-H. LI. 1982. Natural radionuclides as tracers for geochemical processes in MERL mesocosms and Narragansett Bay, p. 97-109. In G. D. Grice [ed.], Marine mesocosms: Biological and chemical research in experimental ecosystems. Springer. 
natural (Th, $\mathrm{Pb}, \mathrm{Po}$ ) and fallout $(\mathrm{Pu}, \mathrm{Cs}, \mathrm{Am})$ radionuclides in the coastal marine environment: Results from model ecosystems (MERL) and Narragansett Bay studies. Geochim. Cosmochim. Acta 47: 201-210.

, Y.-H. LI, J. J. Bell, R. M. TRIER, AND K Kawtaluk. $1980 b$. Pu in coastal marine environments. Earth Planet. Sci. Lett. 51: 248-265. AND S. CARSON. 1980c. The fate of trace metals in Narragansett Bay, Rhode Island: Radiotracer experiments in microcosms. Estuarine Coastal Mar. Sci. 10: 635-654.

__ AND OTHERS. 1987. The relative mobility of radioactive trace elements across the sedimentwater interface of the MERL model ecosystems of Narragansett Bay. J. Mar. Res. 45: 1007-1058. , U. P. NyFFeler, R. F. ANdERSON, S. L. SChifF, AND P. O'HARA. 1986. Response of radioactive trace metals to acid-base titrations in controlled experimental ecosystems: Evaluation of transport parameters for application to whole lake radiotracer experiments. Can. J. Fish. Aquat. Sci. 43: 60-77.

SCHINDLER, D. W. 1973. Experimental approaches to limnology - an overview. J. Fish. Res. Bd. Can. 30: 1409-1413.

, R. H. Hesslein, R. Wagemann, and W. S. BROECKER. 1980. Effects of acidification on mobilization of heavy metals and radionuclides from the sediment of a freshwater lake. Can. J. Fish. Aquat. Sci. 37: 373-377.

Schindler, P. W. 1981. Surface complexes at oxidewater interfaces, p. 1-49. In M. A. Anderson and A. J. Rubin [eds.], Adsorption of inorganics at solid-liquid interfaces. Ann. Arbor. Sci.

SoRoKIN, J. L. 1971. On the role of bacteria in the productivity of tropical oceanic waters. Int. Rev. Gesamten Hydrobiol. 56: 1-48.
Stumm, W., And J. J. Morgan. 1981. Aquatic chemistry. Wiley.

Sunda, W. G., AND R. R. L. Guillard. 1976. The relationship between cupric ion activity and the toxicity of copper to phytoplankton. J. Mar. Res. 34: 511-529.

Sung, W., AND J. J. Morgan. 1981. Oxidative removal of $\mathrm{Mn}$ (II) from solution catalysed by the gamma-FeOOH (lepidocroccite) surface. Gcochim. Cosmochim. Acta 45: 2377-2383.

Takayanagi, K., AND G. T. F. Wong. 1985, Dissolved inorganic and organic selenium in the Orca Basin. Geochim. Cosmochim. Acta 49: 539-546.

TAUBE, H. 1968. Mechanism of oxidation-reduction reactions. J. Chem. Educ. 45: 452-461.

Theis, T. L., AND P. C. Singer. 1974. Complexation of iron(II) by organic mattcr and its effect on iron(II) oxygenation. Environ. Sci. Technol. 8: 569-573.

Turner, D. R., M. Whitfield, AND A. G. Dickson. 1981. The cquilibrium speciation of dissolved components in freshwater and seawater at $25^{\circ} \mathrm{C}$ and $1 \mathrm{~atm}$. pressure. Geochim. Cosmochim. Acta 45: $855-882$.

Turner, M. A., ANd J. W. M. Rudd. 1983. The English-Wabigoon River system. 3. Selenium in lake enclosures: Its geochemistry, bioaccumulation and ability to reduce mercury bioaccumulation. Can. J. Fish. Aquat. Sci. 40: 2228-2240.

Westerlund, S. F. G., AND OTHERs. 1986. Benthic fluxes of $\mathrm{Cd}, \mathrm{Co}, \mathrm{Ni}, \mathrm{Zn}$ and $\mathrm{Pb}$ in the coastal environment. Geochim. Cosmochim. Acta 50: 1289-1296.

Whithow, S. I., AND D. L. Rice. 1985. Silver complexation in river waters of central New York. Water Res. 19: 619-626.

Wood, J. M., AND H. K. WANG. 1985. Strategies for microbial resistance to heavy metals, p. 81-98. In W. Stumm [ed.], Chemical processes in lakes. Wiley. 